\title{
The role of glyoxalases for sugar stress and aging, with relevance for dyskinesia, anxiety, dementia and Parkinson's disease
}

\author{
Georg Auburger and Alexander Kurz
}

\author{
Exp. Neurology, Department of Neurology, Goethe University Medical School, 60590 Frankfurt am Main, \\ Germany
}

Commentary on: Scheckhuber CQ et al. Modulation of the glyoxalase system in the aging model Podospora anserina: effects on growth and lifespan. Aging. 2010; 2: 969-980.

Received: 1/12/11; Accepted: 1/15/11; Published: 1/16/11

Corresponding to: auburger@em.uni-frankfurt.de

(C) Auburger and Kurz. This is an open-access article distributed under the terms of the Creative Commons Attribution License, which permits unrestricted use, distribution, and reproduction in any medium, provided the original author and source are credited

Carbohydrates are the primordial source of energy and carbon for certain unicellular organisms as well as for the complex mammalian brain and its synaptic functions [1]. However, for all these cells the degradation of carbohydrates poses several problems, e.g. the formation of toxic by-products such as the glycating electrophile methylglyoxal (MG, also named 2-oxo-propanal) or the excessive generation of lactic acid with ensuing $\mathrm{pH}$ change [2]. Under conditions of high carbon flux and under limited availability of $\mathrm{NAD}+$, e.g. during anaerobic glycolysis [3], the triose phosphates dihydroxyacetone phosphate and glyceraldehyde-3-phosphate spontaneously decompose to $\mathrm{MG}$, a compound known to contribute to the generation of advanced glycation endproducts (AGEs) [4] - with possibly irreversible damage to lipids, nucleic acids and proteins, in particular of mitochondria [5] and to the induction of ubiquitin conjugates [6]. In a pathway with very high conservation during evolution, all these cells use the enzyme glyoxalase I (lactoylglutathione lyase) in the presence of glutathione (GSH) to convert MG into S-lactoyl-glutathione (SLG) and then use glyoxalase II (hydroxyacylglutathione hydrolase) to liberate D-lactate and glutathione. In spite of this toxicity of MG, some bacteria use the enzyme methylglyoxal synthase to generate $\mathrm{MG}$, apparently to regulate carbon flux and growth rate [7]. Furthermore, the ratio between GSH and SLG in such bacteria modulates potassium efflux and intracellular acidification [8]. Acting as a signal initiator, $\mathrm{MG}$ activates the osmosensor Sln1, the HOG-MAP kinase cascade and the calcium $(2+)$ signalling pathway in yeast [9]. In human cells, MG has a well established anti- proliferative effect in cancerous cells with enhanced glycolysis (Warburg-effect) [10,11]. MG was recently reported to play a physiological role in the modulation of hypoxia-induced-factor-1 $\alpha$ (HIF-1alpha) levels and thus in the modulation of the balance between anaerobic and aerobic bioenergetics [12]. Interestingly, an anxiety-suppressing effect of $\mathrm{MG}$ infusions into the brain was observed in mice [13]. And in patients with hereditary dyskinesias, episodic disorders of spontaneous movement, it is now known that either defects in the cerebral glucose transport or defects in the putative neuronal SLG sensor protein MR-1 can be responsible for these symptoms $[14,15]$. These observations suggest that MG and SLG are not simply toxic by-products to be eliminated, but might play an important physiological function in bioenergetic signaling.

In view of the importance of bioenergetics, sugar stress and growth pathways for the molecular mechanisms of aging, it is hardly surprising that mutations in the glyoxalase pathway affect the survival under carbonyl stress and adverse growth conditions. A stress-protection effect of glyoxalase I overexpression or a sensitizing effect of glyoxalase I deficiency was alredy documented in the bacteria Escherichia coli under anaerobic conditions with high carbon flux [16], the protozoan parasite Leishmania donovani [17], in the yeast Saccharomyces cerevisiae [18], in the plant Nicotiana tabacum [19, 20], in the worm Caenorhabditis elegans [21] and in Rattus norvegicus and Homo sapiens under diabetic sugar stress $[22,23]$. 
The attention of investigators was focused on glyoxalase I, since this enzyme catalyzes the ratelimiting step in the pathway. Furthermore, glyoxalase I is regulated in its expression on the transcript level. Elevated mRNA / protein levels or increased enzyme activity were found to mediate the survival of dental caries bacteria Streptococcus mutans and their continued maintenance of glycolysis in media with high sugar and acid concentrations [24, 25], of Bacillus anthracis, of the fungus Candida albicans and of the worm Onchocerca volvulus under oxidative stress [26-28], of Arabidopsis thaliana under abiotic stress [29], of the high-dormancy seeds of the grass Lolium rigidum Gaud [30], of rice Oryza sativa roots under chilling temperatures or leaves under UV radiation [31, 32], of the tomato Solanum pimpinellifolium as well as the mustard Brassica juncea under salt and heavy metal stress $[33,34]$ and of mammalian cancer cells under stress [35]. However, it is has remained unclear whether increased glyoxalase I levels only serve to protect normal growth and survival under adverse conditions, or whether they are able to postpone aging and increase health at advanced age, as a means to longevity.

Therefore, the recent publication in AGING from investigators around H. Osiewacz in Frankfurt [36] is therefore very important, assessing the relevance of the glyoxalase pathway for growth and lifespan in a model organism that has been very well characterized for more than 50 years within the field of healthy aging organism research, namely the fungus Podospora anserina [37]. This filamentous ascomycete thrives under aerobic conditions and on extracellular glucose, completing a life cycle of germination, maturity with maximal growth, senescence with pigmentation and apical cell death within three weeks. Here, the principal finding of the authors was the extension of the healthy lifespan by $4.3 \%$ through the combined overexpression of glyoxalase I + II under conditions of sugar stress $(2 \%$ glucose), while no lifespan differences were apparent for normal sugar concentrations. No growth differences were apparent under any conditions tested. Importantly and unexpectedly, this study found a reduction of lifespan through strong overexpression of glyoxalase I alone, in contrast to a report of enhanced lifespan after mild glyoxalase I overexpression in C. elegans [21], suggesting that overly strong glyoxalase activity may be toxic due to glutathione depletion with subsequent oxidative stress and possibly potassium efflux. Together with three crucial previous publications from the same team [38-42], these data indicate that a prolongation of healthspan is possible through a network of factors controlling aerobic and anaerobic bioenergetics.

Indeed, these data are of paramount importance for the needs of our modern civilization characterized by excess sugar consumption and an ever older population. They are also a sound scientific basis for future molecular understanding of human aging, where the glyoxalase system has been implicated in senescence and in several age-related disorders. In man, where the promoter of gloxalase $\mathrm{I}$ is inducible by insulin and heavy metals [43], the transcript levels of glyoxalase I show a continuous decrease after the start of senescence at 55 years of age, similar to the decrease of glyoxalase I levels in old rat muscle tissue $[44,45]$. As a biomarker of anxiety, altered expression levels of glyoxalase I were reported in mice, compatible with the hypothesis that low MG levels correlate with anxiety, and an anxiolytic effect of MG infusions into brain was demonstrated [13, 46-49]. Glyoxalase I anomalies were also reported in psychiatric diseases such as mood disorder, schizophrenia and autism, where anxiety symptoms are altered [50-52]. As a biomarker of tau protein pathology in Alzheimer's disease and frontotemporal dementia, increased expression of glyoxalase I was reported in mouse models and patients, and tau aggregation was observed as an effect of elevated MG levels [53-55]. With tau and alphasynuclein being the two most important genetic risk factors of Parkinson's disease (PD) [56] and in view of the co-precipitation of these two proteins in the pathognomonic cytoplasmic "Lewy body" inclusions $[57,58]$, it is interesting that we found an upregulation of glyoxalase I to be the prominent response within the mouse brain transcriptome to a deficient alphasynuclein function [59]. Whether a gain-of-function of alpha-synuclein and other Parkinson triggering events also modulate the glyoxalase system, remains an issue we are investigating, and this seems credible in view of a report on altered glyoxalase I expression in mouse brains with Parkin deficiency [60]. Furthermore, an unexplained glutathione depletion and the presence of AGEs in brain autopsies with incidental Lewy bodies $[61,62]$ suggests an involvement of this pathway in the earliest stages of PD pathogenesis.

Since pharmacological tools are available to selectively antagonize glyoxalase I function [10, 11, 63] and to relieve carbonyl stress [64-67], it is now very promising to have the mutants generated in this publication of AGING [36] as a fast and well-characterized microorganism model of age-related neurodegenerative disease, and to use them to understand and postpone this pathological process. 


\section{REFERENCES}

1. Magistretti PJ. Neuron-glia metabolic coupling and plasticity. J Exp Biol 2006; 209:2304-2311.

2. Lutz PL, Nilsson GE. Contrasting strategies for anoxic brain survival-glycolysis up or down. J Exp Biol 1997; 200:411-419.

3. Hipkiss AR. Mitochondrial dysfunction, proteotoxicity, and aging: causes or effects, and the possible impact of NAD+controlled protein glycation. Adv Clin Chem 2010; 50:123-150.

4. Fleming $\mathrm{TH}$, Humpert PM, Nawroth PP, Bierhaus A. Reactive Metabolites and AGE/RAGE-Mediated Cellular Dysfunction Affect the Aging Process - A Mini-Review. Gerontology 2010 [Epub ahead of print].

5. Rabbani N, Thornalley PJ. Dicarbonyls linked to damage in the powerhouse: glycation of mitochondrial proteins and oxidative stress. Biochem Soc Trans 2008; 36:1045-1050.

6. Bento CF, Marques F, Fernandes R, Pereira P. Methylglyoxal alters the function and stability of critical components of the protein quality control. PLoS One 2010; 5:e13007.

7. Ferguson GP, Totemeyer S, MacLean MJ, Booth IR. Methylglyoxal production in bacteria: suicide or survival? Arch Microbiol 1998; 170:209-218.

8. Ozyamak E, Black SS, Walker CA, Maclean MJ, Bartlett W, Miller S, Booth IR. The critical role of S-lactoylglutathione formation during methylglyoxal detoxification in Escherichia coli. Mol Microbiol 2010; 78:1577-1590.

9. Maeta K, Izawa S, Inoue Y. Methylglyoxal, a metabolite derived from glycolysis, functions as a signal initiator of the high osmolarity glycerol-mitogen-activated protein kinase cascade and calcineurin/Crz1-mediated pathway in Saccharomyces cerevisiae. J Biol Chem 2005; 280:253-260.

10. Thornalley PJ. Pharmacology of methylglyoxal: formation, modification of proteins and nucleic acids, and enzymatic detoxification--a role in pathogenesis and antiproliferative chemotherapy. Gen Pharmacol 1996; 27:565-573.

11. Creighton DJ, Zheng ZB, Holewinski R, Hamilton DS, Eiseman $\mathrm{JL}$. Glyoxalase I inhibitors in cancer chemotherapy. Biochem Soc Trans 2003; 31:1378-1382.

12. Bento CF, Fernandes R, Ramalho J, Marques C, Shang F, Taylor A, Pereira P. The chaperone-dependent ubiquitin ligase CHIP targets HIF-1alpha for degradation in the presence of methylglyoxal. PLoS One 2010; 5:e15062.

13. Hambsch B, Chen BG, Brenndorfer J, Meyer M, Avrabos C, Maccarrone G, Liu RH, Eder M, Turck CW, Landgraf $R$. Methylglyoxal-mediated anxiolysis involves increased protein modification and elevated expression of glyoxalase 1 in the brain. J Neurochem 2010; 113:1240-1251.

14. Weber YG, Storch A, Wuttke TV, Brockmann K, Kempfle J, Maljevic S, Margari L, Kamm C, Schneider SA, Huber SM and others. GLUT1 mutations are a cause of paroxysmal exertioninduced dyskinesias and induce hemolytic anemia by a cation leak. J Clin Invest 2008; 118:2157-2168.

15. Lee HY, Xu Y, Huang $Y$, Ahn AH, Auburger GW, Pandolfo $M$, Kwiecinski $H$, Grimes $D A$, Lang $A E$, Nielsen JE et al. The gene for paroxysmal non-kinesigenic dyskinesia encodes an enzyme in a stress response pathway. Hum Mol Genet 2004; 13:3161-3170. 16. Zhu MM, Skraly FA, Cameron DC. Accumulation of methylglyoxal in anaerobically grown Escherichia coli and its detoxification by expression of the Pseudomonas putida glyoxalase I gene. Metab Eng 2001; 3:218-225.

17. Chauhan SC, Madhubala R. Glyoxalase I gene deletion mutants of Leishmania donovani exhibit reduced methylglyoxal detoxification. PLoS One 2009; 4:e6805.

18. Ispolnov K, Gomes RA, Silva MS, Freire AP. Extracellular methylglyoxal toxicity in Saccharomyces cerevisiae: role of glucose and phosphate ions. J Appl Microbiol 2008; 104:10921102.

19. Singla-Pareek SL, Reddy MK, Sopory SK. Genetic engineering of the glyoxalase pathway in tobacco leads to enhanced salinity tolerance. Proc Natl Acad Sci U S A 2003; 100:14672-14677.

20. Singla-Pareek SL, Yadav SK, Pareek A, Reddy MK, Sopory SK. Transgenic tobacco overexpressing glyoxalase pathway enzymes grow and set viable seeds in zinc-spiked soils. Plant Physiol 2006; 140:613-623.

21. Morcos M, Du X, Pfisterer F, Hutter $H$, Sayed AA, Thornalley $P$, Ahmed N, Baynes J, Thorpe $S$, Kukudov $G$ and others. Glyoxalase-1 prevents mitochondrial protein modification and enhances lifespan in Caenorhabditis elegans. Aging Cell 2008; 7:260-269.

22. Miller AG, Smith DG, Bhat $M$, Nagaraj RH. Glyoxalase I is critical for human retinal capillary pericyte survival under hyperglycemic conditions. J Biol Chem 2006; 281:11864-11871.

23. Brouwers $O$, Niessen PM, Ferreira I, Miyata $T$, Scheffer PG, Teerlink T, Schrauwen P, Brownlee M, Stehouwer CD, Schalkwijk CG. Overexpression of Glyoxalase-I Reduces Hyperglycemiainduced Levels of Advanced Glycation End Products and Oxidative Stress in Diabetic Rats. J Biol Chem 2011; 286:1374-1380.

24. Wilkins JC, Homer KA, Beighton D. Analysis of Streptococcus mutans proteins modulated by culture under acidic conditions. Appl Environ Microbiol 2002; 68:2382-2390.

25. Korithoski B, Levesque CM, Cvitkovitch DG. Involvement of the detoxifying enzyme lactoylglutathione lyase in Streptococcus mutans aciduricity. J Bacteriol 2007; 189:7586-92.

26. Passalacqua KD, Bergman NH, Lee JY, Sherman DH, Hanna PC. The global transcriptional responses of Bacillus anthracis Sterne (34F2) and a Delta sodA1 mutant to paraquat reveal metal ion homeostasis imbalances during endogenous superoxide stress. J Bacteriol 2007; 189:3996-4013.

27. Wang Y, Cao YY, Jia XM, Cao YB, Gao PH, Fu XP, Ying K, Chen WS, Jiang YY. Cap1p is involved in multiple pathways of oxidative stress response in Candida albicans. Free Radic Biol Med 2006; 40:1201-1209.

28. Sommer A, Fischer $P$, Krause $K$, Boettcher K, Brophy PM, Walter RD, Liebau E. A stress-responsive glyoxalase I from the parasitic nematode Onchocerca volvulus. Biochem J 2001; 353:445-452.

29. Mustafiz A, Singh AK, Pareek A, Sopory SK, Singla-Pareek SL. Genome-wide analysis of rice and Arabidopsis identifies two glyoxalase genes that are highly expressed in abiotic stresses. Funct Integr Genomics 2010 [Epub ahead of print].

30. Goggin DE, Powles SB, Steadman KJ. Selection for low or high primary dormancy in Lolium rigidum Gaud seeds results in constitutive differences in stress protein expression and peroxidase activity. J Exp Bot 2010 [Epub ahead of print].

31. Lee DG, Ahsan N, Lee SH, Lee JJ, Bahk JD, Kang KY, Lee BH. Chilling stress-induced proteomic changes in rice roots. J Plant Physiol 2009; 166:1-11. 
32. Du H, Liang Y, Pei K, Ma K. UV Radiation Responsive Proteins in Rice Leaves: a Proteomic Analysiss. Plant Cell Physiol 2010 [Epub ahead of print].

33. Veena, Reddy VS, Sopory SK. Glyoxalase I from Brassica juncea: molecular cloning, regulation and its over-expression confer tolerance in transgenic tobacco under stress. Plant $J$ 1999; 17:385-395.

34. Sun $W, X u X$, Zhu H, Liu A, Liu L, Li J, Hua X. Comparative transcriptomic profiling of a salt-tolerant wild tomato species and a salt-sensitive tomato cultivar. Plant Cell Physiol 2010; 51:997-1006.

35. Ranganathan S, Walsh ES, Tew KD. Glyoxalase I in detoxification: studies using a glyoxalase I transfectant cell line. Biochem J 1995; 309:127-131.

36. Scheckhuber CQ, Mack SJ, Strobel I, Ricciardi F, Gispert S, Osiewacz HD. Modulation of the glyoxalase system in the aging model Podospora anserina: effects on growth and lifespan. Aging 2010; 2:969-980.

37. Scheckhuber CQ, Osiewacz HD. Podospora anserina: a model organism to study mechanisms of healthy ageing. Mol Genet Genomics 2008; 280:365-374.

38. Borghouts C, Werner A, Elthon T, Osiewacz HD. Coppermodulated gene expression and senescence in the filamentous fungus Podospora anserina. Mol Cell Biol 2001; 21:390-399.

39. Scheckhuber CQ, Erjavec N, Tinazli A, Hamann A, Nystrom T, Osiewacz HD. Reducing mitochondrial fission results in increased life span and fitness of two fungal ageing models. Nat Cell Biol 2007; 9:99-105.

40. Luce K, Osiewacz HD. Increasing organismal healthspan by enhancing mitochondrial protein quality control. Nat Cell Biol 2009; 11:852-858.

41. Kunstmann B, Osiewacz HD. Over-expression of an Sadenosylmethionine-dependent methyltransferase leads to an extended lifespan of Podospora anserina without impairments in vital functions. Aging Cell 2008; 7:651-662.

42. Kunstmann B, Osiewacz HD. The S-adenosylmethionine dependent O-methyltransferase PaMTH1: a longevity assurance factor protecting Podospora anserina against oxidative stress. Aging 2009; 1:328-334.

43. Ranganathan S, Ciaccio PJ, Walsh ES, Tew KD. Genomic sequence of human glyoxalase-I: analysis of promoter activity and its regulation. Gene 1999; 240:149-155.

44. Kuhla B, Boeck K, Luth HJ, Schmidt A, Weigle B, Schmitz M, Ogunlade V, Munch G, Arendt T. Age-dependent changes of glyoxalase I expression in human brain. Neurobiol Aging 2006; 27:815-822.

45. Piec I, Listrat A, Alliot J, Chambon C, Taylor RG, Bechet D. Differential proteome analysis of aging in rat skeletal muscle. Faseb J 2005; 19:1143-1145.

46. Kromer SA, Kessler MS, Milfay D, Birg IN, Bunck M, Czibere L, Panhuysen M, Putz B, Deussing JM, Holsboer $F$ and others. Identification of glyoxalase-I as a protein marker in a mouse model of extremes in trait anxiety. J Neurosci 2005; 25:43754384.

47. Hovatta I, Tennant RS, Helton R, Marr RA, Singer $O$, Redwine JM, Ellison JA, Schadt EE, Verma IM, Lockhart DJ and others. Glyoxalase 1 and glutathione reductase 1 regulate anxiety in mice. Nature 2005; 438:662-666.

48. Ditzen C, Jastorff AM, Kessler MS, Bunck M, Teplytska L, Erhardt A, Kromer SA, Varadarajulu J, Targosz BS, Sayan-Ayata EF and others. Protein biomarkers in a mouse model of extremes in trait anxiety. Mol Cell Proteomics 2006; 5:1914-1920.

49. Williams Rt, Lim JE, Harr B, Wing C, Walters R, Distler MG, Teschke M, Wu C, Wiltshire T, Su Al and others. A common and unstable copy number variant is associated with differences in Glo1 expression and anxiety-like behavior. PLoS One 2009; 4:e4649.

50. Fujimoto M, Uchida S, Watanuki T, Wakabayashi Y, Otsuki K, Matsubara T, Suetsugi M, Funato $H$, Watanabe $Y$. Reduced expression of glyoxalase-1 mRNA in mood disorder patients. Neurosci Lett 2008; 438:196-199.

51. Arai $M$, Yuzawa $H$, Nohara I, Ohnishi $T$, Obata $N$, Iwayama $Y$, Haga S, Toyota T, Ujike H, Arai M and others. Enhanced carbonyl stress in a subpopulation of schizophrenia. Arch Gen Psychiatry 2010; 67:589-597.

52. Junaid MA, Kowal D, Barua M, Pullarkat PS, Sklower Brooks $S$, Pullarkat RK. Proteomic studies identified a single nucleotide polymorphism in glyoxalase I as autism susceptibility factor. Am J Med Genet A 2004; 131:11-17.

53. Chen F, Wollmer MA, Hoerndli F, Munch G, Kuhla B, Rogaev EI, Tsolaki M, Papassotiropoulos A, Gotz J. Role for glyoxalase I in Alzheimer's disease. Proc Natl Acad Sci U S A 2004; 101:76877692.

54. Kuhla B, Boeck K, Schmidt A, Ogunlade V, Arendt T, Munch $\mathrm{G}$, Luth HJ. Age- and stage-dependent glyoxalase I expression and its activity in normal and Alzheimer's disease brains. Neurobiol Aging 2007; 28:29-41.

55. Guix FX, III-Raga G, Bravo R, Nakaya T, de Fabritiis G, Coma $M$, Miscione GP, Villa-Freixa J, Suzuki T, Fernandez-Busquets $X$ and others. Amyloid-dependent triose-phosphate isomerase nitrotyrosination induces glycation and tau fibrillation. Brain 2009; 132:1335-1345.

56. Simon-Sanchez J, Schulte C, Bras JM, Sharma M, Gibbs JR, Berg D, Paisan-Ruiz C, Lichtner P, Scholz SW, Hernandez DG and others. Genome-wide association study reveals genetic risk underlying Parkinson's disease. Nat Genet 2009; 41:1308-1312.

57. Giasson BI, Forman MS, Higuchi M, Golbe LI, Graves CL, Kotzbauer PT, Trojanowski JQ, Lee VM. Initiation and synergistic fibrillization of tau and alpha-synuclein. Science 2003; 300:636640.

58. Kotzbauer PT, Giasson BI, Kravitz AV, Golbe LI, Mark MH, Trojanowski JQ, Lee VM. Fibrillization of alpha-synuclein and tau in familial Parkinson's disease caused by the A53T alphasynuclein mutation. Exp Neurol 2004; 187:279-288.

59. Kurz A, Rabbani N, Walter $M$, Bonin $M$, Thornalley $P$, Auburger G, Gispert S. Alpha-synuclein deficiency leads to increased glyoxalase I expression and glycation stress. Cell Mol Life Sci 2010 [Epub ahead of print].

60. Palacino JJ, Sagi D, Goldberg MS, Krauss S, Motz C, Wacker M, Klose J, Shen J. Mitochondrial dysfunction and oxidative damage in parkin-deficient mice. J Biol Chem 2004; 279:1861418622.

61. Dexter DT, Sian J, Rose S, Hindmarsh JG, Mann VM, Cooper JM, Wells FR, Daniel SE, Lees AJ, Schapira AH and others. Indices of oxidative stress and mitochondrial function in individuals with incidental Lewy body disease. Ann Neurol 1994; 35:38-44.

62. Munch G, Luth HJ, Wong A, Arendt T, Hirsch E, Ravid R, Riederer P. Crosslinking of alpha-synuclein by advanced glycation endproducts--an early pathophysiological step in Lewy body formation? J Chem Neuroanat 2000; 20:253-257. 
63. Wu L, Eftekharpour E, Davies GF, Roesler WJ, Juurlink BH. Troglitazone selectively inhibits glyoxalase I gene expression. Diabetologia 2001; 44:2004-2012.

64. Johansson AS, Ridderstrom $M$, Mannervik $B$. The human glutathione transferase P1-1 specific inhibitor TER 117 designed for overcoming cytostatic-drug resistance is also a strong inhibitor of glyoxalase I. Mol Pharmacol 2000; 57:619-624.

65. Dukic-Stefanovic S, Schinzel R, Riederer P, Munch G. AGES in brain ageing: AGE-inhibitors as neuroprotective and antidementia drugs? Biogerontology 2001; 2:19-34.

66. de Arriba SG, Stuchbury G, Yarin J, Burnell J, Loske C, Munch G. Methylglyoxal impairs glucose metabolism and leads to energy depletion in neuronal cells--protection by carbonyl scavengers. Neurobiol Aging 2007; 28:1044-1050.

67. Hipkiss AR. Aging, Proteotoxicity, Mitochondria, Glycation, NAD and Carnosine: Possible Inter-Relationships and Resolution of the Oxygen Paradox. Front Front Aging Neurosci 2010; 2:10. 